\title{
STUDI ANALISIS TENTANG MAKNA PENGETAHUAN DAN ILMU PENGETAHUAN SERTA JENIS DAN SUMBERNYA
}

\section{ANALYTICAL STUDIES ON THE MEANING OF KNOWLEDGE AND SCIENCE AND ITS TYPES AND SOURCES}

\author{
Muannif Ridwan ${ }^{1}$ \\ ${ }^{1} \mathrm{Ph} . \mathrm{D}$ student of Sultan Thaha Saifuddin State Islamic University Jambi \& Lecturer in Islamic \\ University Of Indragiri, Tembilahan-Riau. \\ anifr@ymail.com
}
Ahmad Syukri
${ }^{2}$ Professor of Sultan Thaha Saifuddin State Islamic University Jambi-Indonesia. ahmadsukriss@uinjambi.ac.id

\author{
Badarussyamsi $^{3}$ \\ ${ }^{3}$ Senior Lecturer of Sultan Thaha Saifuddin State Islamic University Jambi-Indonesia. \\ badarussyamsi76@gmail.com, badarussyamsi1976@gmail.com
}

\begin{abstract}
ABSTRAK
Ilmu pengetahuan memiliki kedudukan yang tinggi dalam sejarah peradaban manusia. Kebutuhan manusia akan adanya ilmu pengetahuan sangat mendesak, setiap orang pasti merasakan dalam dirinya pentingnya ilmu pengetahuan. Jika manusia hilang dalam dirinya rasa haus akan ilmu, maka kehancuran akan menghampirinya. Sebab rasa ingin tahu adalah fitrah bagi manusia yang diciptakan Allah sebagai mahluk yang selalu bertanya dan ingin tahu akan eksistensi sesuatu. Tulisan ini membahas mengenai dasar-dasar pengetahuan yang mencakup definisi, sumber, dan jenis-jenis pengetahuan, dan juga mengenai jenis-jenis ilmu pengetahuan yang mencakup definisi, dan ciri-cirinya, serta dibahas juga terkait persamaan dan perbedaan antara pengetahuan dan ilmu pengetahuan dan cabang-cabang dari ilmu pengetahuan. Penelitian ini menggunakan pendekatan deskriptif kualitatif dengan jenis penelitian yang digunakan adalah studi kepustakaan (library research), yaitu mengumpulkan data atau karya tulis ilmiah yang berkaitan dengan filsafat ilmu yang bersifat kepustakaan. Dari penelitian ini diharapakan pembaca dapat memahami hakikat ilmu pengetahuan, sumber, ciri-ciri, dan jenis-jenisnya serta persamaan dan perbedaan antara pengetahuan dan ilmu pengetahuan secara komprehensif, sehingga pembaca dalam kehidupan sehari-harinya dapat termotivasi untuk terus berproses dalam mencari ilmu pengetahuan dengan berbagai metode dan konsep-konsep, baik melalui proses pendidikan maupun melalui pengalaman.
\end{abstract}

Kata Kunci: Pengetahuan, Ilmu Pengetahuan, Jenis dan Sumbernya 


\begin{abstract}
Science has a high position in the history of human civilization. The human need for knowledge is very urgent, everyone must feel in him the importance of science. If man loses in himself the thirst for knowledge, then destruction will come upon him. Because curiosity is a natural fit for humans, which Allah created as a creature who always asks and wants to know the existence of something. This paper discusses the basics of knowledge which includes definitions, sources, and types of knowledge, and also about the types of knowledge that include definitions, and their characteristics, and also discusses the similarities and differences between knowledge and science and branches of science. This research usesA qualitative descriptive approach with the type of research used is library research, which is collecting data or scientific papers related to the philosophy of science that is library in nature. From this research, it is hoped that readers can understand the nature of science, its sources, characteristics, and types as well as the similarities and differences between knowledge and science in a comprehensive manner, so that readers in their daily lives can be motivated to continue the process of seeking knowledge by various methods and concepts, both through the educational process and through experience.
\end{abstract}

Keywords: Basic, type, Knowledge, Science.

\section{PENDAHULUAN}

Ilmu pengetahuan (science) terdiri dari seperangkat pengetahuan yang digunakan untuk mencari, menemukan, dan meningkatkan pemahaman atas suatu masalah yang menjadi kajian dengan menggunakan seperangkat konsep dan teori, dan dengan menggunakan seperangkat metode ilmiah yang objektif, metodologis, sistematik, dan universal. Maka dari itu, sebuah ilmu pengetahuan secara hakiki harus dapat dijelaskan tentang apa yang menjadi objek kajiannya (ontologi), bagaimana ilmu pengetahuan itu terbentuk dan apa yang membentuk batang tubuhnya (epistemologi), apa manfaatnya bagi umat manusia (aksiologi), serta bagaimana prosedur untuk mempelajarinya (metodologi).

Ilmu merupakan bagian dari pengetahuan yang objek telaahnya adalah dunia empiris dan proses mendapatkan pengetahuannya sangat ketat, yaitu menggunakan metode ilmiah. Ilmu menggabungkan logika deduktif dan induktif, dan penentu kebenaran ilmu tersebut adalah dunia empiris yang merupakan sumber dari ilmu itu sendiri.

Dalam Islam manusia dituntut agar terus mencari ilmu karena amal tanpa ilmu tidak lebih dari sekedar kesesatan, bahkan ayat pertama yang turun dalam al-Quran surat al-Alaq adalah iqra (bacalah), ayat ini ditujukan kepada umat Islam dan bersifat perintah dalam menuntut ilmu, karena salah satu wasilah dalam menuntut ilmu adalah membaca.

Al-Ghazali mengelompokkan ilmu menjadi fardlu 'ain dan fardu kifayah. Fardlu 'ain menunjukkan ilmu-ilmu yang terkait dengan perintah dan larangan agama. Fardlu kifayyah 
mencakup ilmu-ilmu yang penguasaannya wajib bagi suatu masyarakat Muslim tapi tidak mengikat bagi tiap individu. Ilmu fardlu kifayyah terbagi menjadi dua, yaitu ilmu-ilmu agama (syar'iyyah), yang diambil dan berkisar tentang wahyu Allah dan Sunnah Rasul, seperti ilmu tafsir, hadith, fiqh, ushul fiqh, dan lain-lain, serta ilmu non agama (ghairu syar'iyyah) yang berasal dari hasil penalaran akal manusia, pengalaman, dan percobaan, seperti kedokteran, matematika, ekonomi, astronomi, dan lain. Ilmu ini berkaitan dengan fisik dan objek-objek yang berhubungan dengannya, yang dapat dicapai melalui penggunaan daya intelektual dan jasmaniah (Imam al-Ghazali, tanpa tahun: 244.);

Sejatinya filsafat ilmu itu mempelajari dan mempertanyakan secara sistematis mengenai hakikat ilmu pengetahuan yang berhubungan dengan masalah-masalah filosofis dan fundamental yang terdapat pada ilmu untuk mencapai pengetahuan yang ilmiah. Beberapa pandangan mengenai Filsafat Ilmu, sebagaimana hasil bacaan penulis, diantaranya filsafat ilmu merupakan suatu tinjauan kritis tentang pendapatpendapat ilmiah. Filsafat ilmu adalah perbandingan atau pengembangan pendapatpendapat masa lampau terhadap pendapatpendapat kontemporer yang didukung dengan bukti-bukti ilmiah. Filsafat ilmu merupakan paparan dugaan dan kecenderungan yang tidak terlepas dari pemikiran para ilmuwan yang menelitinya.

Maka filsafat ilmu dapat dimaknai sebagai suatu disiplin, konsep, dan teori tentang ilmu yang sudah dianalisis serta diklasifikasikan. Filsafat ilmu adalah perumusan pandangan tentang ilmu berdasarkan penelitian secara ilmiah. Ketika filsafat dikatakan sebuah sebuah disiplin ilmu, disebut sebagai akar dari sebuah ilmu pengetahuan itu sendiri, disini diambil pertanyaan balik pada filsafat itu sendiri, sejauh mana kontribusi yang diberikan oleh filsafat ilmu kepada ilmu Pengetahuan.

Tegasnya, filsafat ilmu hendak menunjukkan bahwa filsafat adalah ilmu berpikir atau seni mengolah pikir untuk menghasilkan karya-karya keilmuan dan karya budaya yang berguna. Melalui itu, mahasiswa dibimbing untuk memahami bagimana pikiran sebagai daya intelektual manusia telah menjadi kekuatan peradaban dan budaya yang telah menghasilkan kemajuan-kemajuan besar dalam hidup dan menjadikannya sebagai master budaya.

Melalui Filsafat ilmu, kita dapat membangun kemampuan dalam mengolah pikir guna mengkritisi berbagai pemikiran keilmuan serta makin terbimbing untuk menghasilkan karya-karya keilmuan dan karya budaya yang berguna, sesuai bidang keahliannya. Inti pembangunan ilmu bertumpu pada tiga dimensi keilmuan, yaitu: 
Pertama; dimensi kritis, dengan tujuan untuk membangun otonomi diri serta kemampuan nalar dalam menilai dan mempertanyakan berbagai kemungkinan (klaim-klaim kebenaran bersifat keilmiahan, ideologis, yuridis, maupun religius) dalam rangka pengembangan dan penegasan eksistensi (pilihan hidup), Kedua; dimensi kreatif, dengan tujuan untuk mengolah budi (kecerdasan), mampu melakukan imajinasi teori, mengubah fakta menjadi permasalahan dan terobosan penyelesaiannya dalam berbagai lakon actual, Ketiga; dimensi kontemplatif untuk menajamkan kepekaan, mampu mengenal kekuatan dan kelemahan, serta menasehati dan membimbing diri (menangani diri) sehingga memiliki sebuah jangkar keberadaan dan pondasi eksistensi yang kokoh sebagai pribadi (personal), maupun sebagai bangsa, dan masyarakat yang beradab dan bermartabat.

Berdasarkan atas pengertian yang ada dan berdasarkan atas kebiasaan yang terjadi, sering ditemukan kerancuan antara pengertian ilmu dengan pengetahuan. Kedua kata tersebut dianggap memiliki persamaan arti, bahkan ilmu dan pengetahuan terkadang dirangkum menjadi satu kata majemuk yang mengandung arti tersendiri. Hal ini sering kita jumpai dalam berbagai karangan yang membicarakan tentang ilmu pengetahuan. $\begin{array}{lcc}\text { Bahkan dalam Kamus Besar } & \text { Bahasa } \\ \text { Indonesia ilmu disamakan } & \text { dengan }\end{array}$ pengetahuan, sehingga ilmu adalah pengetahuan. Namun jika kata pengetahuan dan kata ilmu tidak dirangkum menjadi satu kata majemuk atau berdiri sendiri, akan tampak perbedaan antara keduanya. Berdasarkan asal katanya, pengetahuan diambil dari kata dalam bahasa Inggris yaitu knowledge. Sedangkan ilmu berasal dari kata Science. Tentunya dari dua kata itu mempunyai makna yang berbeda.

Oleh sebab itu, tulisan ini berusaha menjelaskan mengenai dasar-dasar pengetahuan yang mencakup definisi, sumber, dan jenis-jenis pengetahuan, dan juga mengenai jenis-jenis ilmu pengetahuan yang mencakup definisi, dan ciri-cirinya, serta dibahas juga terkait persamaan dan perbedaan antara pengetahuan dan ilmu pengetahuan dan cabang-cabang dari ilmu pengetahuan.

\section{URGENSI PENELITIAN}

Filsafat adalah hal yang penting dalam kehidupan, mampu menjawab segala pertanyaan dengan metode berpikir yang logis dan tidak terikat norma dan dogma. Adapun urgensi dari mengkaji filsafat Ilmu adalah untuk penalaran manusia dalam membangun ilmu. Sebab, Filsafat Ilmu akan menyelidiki, menggali, dan menelusuri sedalam, sejauh, dan seluas mungkin semua tentang hakikat Ilmu. Dalam hal ini, kita bisa mendapatkan gambaran bahwa filsafat ilmu merupakan akar dari semua ilmu dan pengetahuan. 
Berikut adalah alasan yang paling fundamental mengapa kita harus mengkaji dan mengembangkan filsafat ilmu sebagai pengetahuan yang harus dimiliki, antara lain:

\section{Menjadi Seorang Yang Kritis; Dengan} belajar filsafat, kita bisa memiliki pemikiran yang kritis. Filsafat akan membentuk pemikiran diplomatis, yang bisa menjadikan kita peka terhadap lingkungan sekitar, dan juga bertindak anti apatis.

2. Mampu Berpikir Secara Rasional dan Logis; Filsafat bisa membentuk kita menjadi seorang pemikir yang logis dan rasional. Dengan metode berpikir seperti ini, kita bisa mengatasi masalah-masalah dalam kehidupan dengan baik.

3. Berpikir Independen; Pemikiran independen adalah hasil berpikir secara pragmatis dan terbuka. Kita juga harus berusaha mengambil jalan tengah agar tidak ada pihak-pihak yang dirugikan. Memang berpikir secara konvensional akan membuat hidup menjadi sistematis, tapi berpikir secara independen membuat kita bisa melangkah lebih jauh. Selain itu, berpikir independen berarti tidak 'hidup' berdasar pemikiran orang lain.

4. Berpikir Secara Fleksibel; Filsafat itu sifatnya dinamis, tidak terbelenggu dalam satu aturan-aturan dan kaidah. Ini akan membuat kita memiliki fleksibilitas berpikir, memiliki kemauan untuk mencoba hal baru. Tidak harus 'terikat' dengan ide-ide lama, karena kita bisa menggantinya dengan ide-ide baru yang lebih efektif.

5. Memperluas wawasan; Memiliki wawasan yang luas akan membuat kita lebih terampil di berbagai bidang. Ingat, peradaban dunia dibangun berdasar dari berbagai macam pemikiran. Di samping itu, peserta didik akan memahami berbagai macam teori-teori dalam kehidupan, sehingga menjadi menjadi sadar, betapa berharganya kehidupan.

6. Mampu Menganilis Setiap Permasalahan; Filsafat mengajarkan kita untuk bisa mempertahankan pendapat, serta bisa mengembangkannya secara sehat, menggunakan nalar yang tepat, tidak menggunakan otot dan tidak menggunakan ototritas intervensi.

7. Menjadi seorang yang skeptis; Bukan berarti kita harus menjadi agnostik atau atheis, namun ini lebih ke arah bagaimana mereka mengamati lingkungan dan situasi sekitar. Menjadi seorang yang skeptis berarti tidak langsung percaya pada suatu peristiwa atau berita, tapi kita harus bisa menemukan bukti yang kredibel serta valid, agar tidak termakan berita hoax.

8. Memahami Bahwa Segala Sesuatu Yang Terjadi Berdasar Sebab-Akibat; Prinsip ini disebut juga kausalitas, bahwa segala sesuatu yang terjadi pasti ada sebab yang 
mengawalinya. Ketika mereka ditanya tentang bagaimana sesuatu bisa terjadi, mereka tidak lagi menjawab "tidak tahu", karena mereka sudah memiliki jawabannya.

9. Menjawab segala pertanyaan tentang kehidupan; Pada dasarnya, Filsafat adalah jawaban dari setiap pertanyaan. Mungkin di benak kita sering terlintas pertanyaan seperti, "Siapa kita?", "Untuk apa kita hidup?", "Apa itu kehidupan?". Kita bisa menemukan metode dan cara yang tepat, untuk bisa memahami dan menjawab pertanyaan-pertanyaan itu melalui belajar filsafat.

\section{METODE, JENIS, DAN TUJUAN PENELITIAN}

Penelitian ini menggunakan metode deskriptif kualitatif dengan jenis penelitian yang digunakan adalah studi kepustakaan (library research), yaitu mengumpulkan data atau karya tulis ilmiah yang berkaitan dengan filsafat ilmu yang bersifat kepustakaan. Penelitian deskriptif kualitatif merupakan gabungan penelitian deskriptif dan kualitatif. Penelitian deskriptif kualitatif menampilkan hasil data apa adanya tanpa proses manipulasi atau perlakuan lain.

Adapun metode deskriptif kualitatif menurut I Made Winartha, metode analisis deskriptif kualitatif adalah menganalisis, menggambarkan, dan meringkas berbagai kondisi, situasi dari berbagai data yang dikumpulkan berupa hasil wawacara atau pengamatan mengnai masalah yang diteliti yang terjadi di lapangan (I Made Winartha, 2006: 24); Sedangkan Menurut Sugiyono, penelitian kualitatif deskriptif adalah metode penelitian yang berlandaskan pada filsafat postpositivisme yang biasanya digunakan untuk meneliti pada kondisi objektif yang alamiah dimana peneliti berperan sebagai instrumen kunci (Sugiyono, 2008: 15)

Tujuan dari penelitian ini agar pembaca dapat memahami hakikat ilmu pengetahuan, sumber, ciri-ciri, dan jenis-jenisnya serta persamaan dan perbedaan antara pengetahuan dan ilmu pengetahuan secara komprehensif, sehingga pembaca dalam kehidupan sehariharinya dapat termotivasi untuk terus berproses dalam mencari ilmu pengetahuan dengan berbagai metode dan konsep-konsep, baik melalui proses pendidikan maupun melalui pengalaman.

\section{POKOK KAJIAN PENELITIAN}

Untuk mempermudah memahami pembahasan pada penelitian ini, maka penulis akan membahas beberapa pokok penting dalam tulisan ini mengenai ilmu antara lain:

1. Dasar-dasar Pengetahuan, mencakup;

a. Definisi Pengetahuan

b. Sumber Pengetahuan

c. Jenis-jenis Pengetahuan 
2. Jenis-jenis Ilmu Pengetahuan, mencakup;
a. Definisi Ilmu Pengetahuan
b. Ciri-ciri Ilmu Pengetahuan
c. Jenis-jenis Ilmu Pengetahuan

3. Persamaan dan Perbedaan Antara Pengetahuan dan Ilmu Pengetahuan

4. Cabang-cabang Ilmu Pengetahuan

\section{DASAR-DASAR PENGETAHUAN}

\section{Definisi Pengetahuan}

Mengenai definisi pengetahuan ini, penulis mencoba memberikan beberapa uraian dalam pembahasan ini. Dalam dalam bahasa inggris pengetahuan disebut knowledge. Adapun menurut kamus terbitan Kementerian Pendidikan dan Kebudayaan Republik Indonesia, pengetahuan adalah segala sesuatu yang diketahui, misalnya kepandaian, atau segala sesuatu yang diketahui berkenaan dengan hal, contohnya mata pelajaran. Pengetahuan juga bisa diartikan sebagai sebuah bentuk pengalaman (Https://Kbbi.Kemdikbud.Go.Id/Entri/Penget ahuan), contohnya adalah suatu bentuk dimana akan ada pemikiran orang yang berasal dari jaman dahulu dimana mempunyai sebuah pendapat jika dengan mengoleskan sebuah daun yang sudah dikunyah atau dibasahkan dengan air liur manusia, maka sebuah luka, maka luka tersebut akan menjadi lebih cepat sembuh. Walaupun demikian, hal ini tentu belumlah bisa dibuktikan atau dipastikan kebenarannya. Dengan begitu, perlu diketahui apakah sembuhnya dikarenakan ludah ataupun luka yang dideritanya tersebut sembuh hanya karena sebuah kebetulan semata.

Pengetahuan juga bisa didefinisikan atau diberi batasan sebagaimana berikut:

1. Sesuatu yang ada atau dianggap ada

2. Sesuatu hasil persesuaian subjek dengan objek

3. Hasil kodrat manusia ingin tahu

4. Hasil persesuaian antara induksi dengan deduksi

(Http://Referensiassyariabdullah.Blogspot. Com/2008/04/Definisi-Dan-Jenis-Jenis-

Pengetahuan.Html Diakses Pada 29-102020 Pukul 17:39 WIB.);

Selain definisi yang ada di atas, dalam kitab klasik ilmu logika, Pengetahuan itu didefinisikan sebagai suatu gambaran objekobjek eksternal yang hadir dalam pikiran manusia

(Http://Isyraq.Wordpress.Com/2007/11/26/Su bstansi-Dan-Definisi-Pengetahuan/Diakses pada 29-10-2020 Pukul 17.41 WIB); Sementara definisi pengetahuan ini sebenarnya masih menjadi perdebatan di kalangan para ahli sampai saat ini, walaupun Plato sendiri sudah menyatakan sebagaimana ditulis Navel Oktaviandry, bahwa pengetahuan itu sebagai "kepercayaan sejati yang dibenarkan (valid)"/“justified true belief'. Sedangkan menurut Notoatmodjo (2003), pengetahuan merupakan hasil dan ini 
STUDI ANALISIS TENTANG MAKNA PENGETAHUAN DAN ILMU PENGETAHUAN SERTA JENIS DAN SUMBERNYA

Muannif Ridwan, Ahmad Sukri, Badrussyamsi

terjadi setelah orang melakukan penginderaan terhadap suatu obyek tertentu (Http://Navelmangelep.Wordpress.Com/ 2012/02/21/Pengetahuan-PengetahuanIlmiah-Penelitian-Ilmiah-Dan-JenisPenelitian/ diakses Pada 29 Oktober 2020);

Berdasarkan uraian-uraian di atas, dapat ditarik kesimpulan bahwa definisi pengetahuan adalah hasil dari proses mencari tahu, dari yang tadinya tidak tahu menjadi tahu, dari tidak dapat menjadi dapat. Dalam proses mencari tahu ini mencakup berbagai metode dan konsep-konsep, baik melalui proses pendidikan maupun melalui pengalaman. Ciri pokok dalam taraf pengetahuan adalah ingatan tentang sesuatu yang diketahuinya baik melalui pengalaman, belajar, ataupun informasi yang diterima dari orang lain.

Pengetahuan diawali dari rasa ingin tahu yang ada dalam diri manusia. Pengetahuan selama ini diperoleh dari proses bertanya dan selalu di tujukan untuk menemukan kebenaran. Di dalam filsafat ilmu, pengetahuan itu disebut pengetahuan yang benar jika telah memenuhi beberapa kriteria kebenaran. Kriteria kebenaran tersebut didasarkan pada beberapa teori antara lain:

\section{Teori Koherensi (Theory of Coherence)}

Berdasarkan teori ini, suatu pengetahuan dianggap benar apabila pengetahuan tersebut kehoren dengan pengetahuan yang ada sebelumnya dan sudah dibuktikan kebenarannya. Didalam pembelajaran matematika hal ini biasanya disebut dengan sifat deduktif.

2. Teori-Korespondensi

\section{Corespondence)}

Berdasarkan teori ini, suatu pengetahuan dianggap benar jika pengetahuan tersebut mempunyai hubungan dengan suatu kenyataan yang memang benar. Teori ini didasarkan pada fakta empiris sehingga pengetahuan tersebut benar apabila ada faktafakta yang mendukung bahwa pengetahuan tersebut benar. Dengan demikian kebenaran disini didasarkan pada kesimpulan induktif.

\section{Teori Pragmatis (Theory of Pragmatism)}

Menurut teori ini, pengetahuan dikatakan benar apabila pengetahuan tersebut terlihat secara praktis benar atau memiliki sifat kepraktisan yang benar. Pengikut teori ini berpendapat bahwa pengetahuan itu benar apabila mempunyai keguanaan yang praktis (Anisa Sholikhati dkk., 2012: 3-4);

\section{Sumber Pengetahuan}

Pengetahuan yang dimiliki manusia dalam kajian filsafat dijelaskan bahwa itu memiliki sumber, artinya pengetahuan itu tidak timbul dengan sendirinya. Ada empat sumber pengetahuan yang dimaksud, yaitu Rasio, Empiris, Intuisi, dan Wahyu. Keempat sumber ini memiliki pengertian yang berbedabeda dalam menafsirkan sumber dari pengetahuan manusia tersebut. 
1. Rasio, merupakan pengetahuan yang bersumber dari penalaran manusia. Pada sumber pengetahuan ini diketahui bahwa pengetahuan adalah hasil pemikiran manusia.

2. Empiris, merupakan pengetahuan yang bersumber dari pengalaman yang dialami manusia. Sumber pengetahuan ini dirumuskan berdasarkan kegiatan manusia yang suka memperhatikan gejala-gejala yang terjadi disekitarnya. Misalnya peristiwa terjadinya hujan di bumi. Peristiwa ini terus terulang-ulang dan dengan proses kejadian yang sama. Hal ini menjadi daya tarik bagi manusia, muncul pertanyaan mengapa selalu turun hujan. Dari pengalaman itulah manusia tergerak untuk bernalar hingga melakukan penelitian penyebab terjadinya hujan.

Intuisi, merupakan sumber pengetahuan yang tidak menentu dan didapatkan secara tibatiba. Terkadang kita sebagai manusia ketika dihadapkan dengan suatu permasalahan, otak akan berpikir sangat keras untuk menemukan solusi dari permasalahan tersebut. Tingkat berpikir otak berbanding lurus dengan masalah yang akan diselesaikan. Semakin sulit tingkat permaslahan yang akan dipecahkan semakin keras juga kinerja otak dalam berpikir menyelesaikan masalah tersebut. Dalam kondisi tertentu, terkadang semakin kita berusaha untuk memecahkan masalah, semakin sulit menemukan solusinya.
Tapi dalam kondisi yang berlawanan ketika kita tidak sedang berpikir untuk menyelesaikan masalah dan melakukan aktivitas-aktivitas, kita seakan terpikirkan solusi untuk permasalahan. Solusi itu muncul tiba-tiba dalam benak kita, tanpa sedikitpun kita menjadwalkan atau berusaha mencarinya. Hal yang demikian bisa dikatakan sebagai intuisi (Bambang Irawan, Vol. 25, No. 1, JanJun 2014);

Wahyu, atau bisa dikatakan dengan sumber pengetahuan yang non-analitik karena tidak ada proses berpikir dari manusia tersebut. Wahyu merupakan sumber pengetahuan yang berasal dari yang Maha kuasa. Biasanya yang dapat menerima sumber pengetahuan yang seperti ini adalah manusia-manusia pilihan. Contoh yang paling dekat adalah para nabiallah, yang menerima pengetahuan dari Allah. Kisah-kisah merekapun banyak mengispirasi banyak orang (https://sites.google.com/site/auroranight0912 /filsafat-ilmu/sumber-pengetahuan diakses pada 29-10-2020 pukul 18.52 WIB);

Dapat disimpulkan dari keempat sumber pengetahuan di atas, bahwa cara berpikir itu ada dua, yaitu analitik; Rasio dan Empiris. Dikatakan sebagai cara berpikir yang analitik karena ada proses berpikir yang rinci yang dilakukan manusia. Ada pula cara berpikir yang non-analitik; intuisi dan wahyu yang tidak memiliki proses berpikir secara rinci yang dilakukan oleh manusia 
STUDI ANALISIS TENTANG MAKNA PENGETAHUAN DAN ILMU PENGETAHUAN SERTA JENIS DAN SUMBERNYA

Muannif Ridwan, Ahmad Sukri, Badrussyamsi

(https://sites.google.com/site/auroranight0912

/filsafat-ilmu/sumber-pengetahuan diakses pada 29-10-2020 pukul 18.52 WIB)

Sementara dalam hakikat penalaran ilmiah terbagi atas dua, yaitu deduktif yang berhubungan dengan rasional, dan induktif yang berdasarkan empiris atau pengalaman dan data lapangan. Keduanya dikombinasikan agar dapat ditarik kesimpulan dari penalaran ilmiah tersebut. Dalam penarikan kesimpulan pun harus menggunakan logika induktif dan logika deduktif. Setelah penarikan kesimpulan, menguji kebenaran dari suatu penalaranpun perlu dilakukan. Suatu penalaran dianggap benar jika koherensi, korespondensi, dan pragmatis atau ada manfaatnya.

Sehingga sumber pengetahuan disini meliputi dua macam, yaitu Empirisme (Indera). Indera adalah alat atau pun sumber pengetahuan manusia untuk mengetahui objek-objek fisik dengan perantaraannya, dan empiris disini di jadikan sebagai pengalaman indera sebagai sumber pengetahuan. Dan segala sesuatu yang tidak bisa di jangkau atau tidak bisa capai oleh indera maka itu bukalah pengetahuan yang sesungguhnya (benar). Sedangkan Rasionalisme (akal) adalah pengetahuan yang di hasilkan oleh proses belajar mengajar, pengkajian buku serta lembaga-lembaga pendidikan, dan rasional disini tidaklah mengingkari penggunaan indera, namun indera disini hanyalah perantara ataupun perangsang agar supaya akal lebih berfikir dan menemukan kebenaran yang sesungguhnya

(https://www.kompasiana.com/indah98930/5d a890d40d82303b934f4032/sumber-sumberpengetahuan-dan-macam-macam-dimensifilsafat-ilmu?page=2 diakses pada 29-102020 pukul 19.13 WIB)

\section{Jenis-jenis Pengetahuan}

Pengetahuan dapat dimiliki manusia di dalam kehidupannya. Akan tetapi pada umumnya pengetahuan itu dibagi menjadi beberapa jenis diantaranya:

a. Pengetahuan Langsung (immediate)

Pengetahuan langsung adalah pengetahuan langsung yang hadir dalam jiwa tanpa melalui proses penafsiran dan pikiran. Kaum realis (penganut paham Realisme) mendefinisikan pengetahuan seperti itu. Umumnya dibayangkan bahwa kita mengetahui sesuatu itu sebagaimana adanya, khususnya perasaan ini berkaitan dengan realitas-realitas yang telah dikenal sebelumnya seperti pengetahuan tentang pohon, rumah, binatang, dan beberapa individu manusia. Namun, apakah perasaan ini juga berlaku pada realitas-realitas yang sama sekali belum pernah dikenal dimana untuk sekali melihat kita langsung mengenalnya sebagaimana hakikatnya? Apabila kita sedikit mencermatinya, maka akan nampak dengan jelas bahwa hal itu tidaklah demikian adanya. 


\section{b. Pengetahuan Tidak Langsung (mediated)}

Pengetahuan tidak langsung adalah hasil dari pengaruh interpretasi dan proses berpikir serta pengalaman-pengalaman yang lalu. Apa yang kita ketahui dari benda-benda eksternal banyak berhubungan dengan penafsiran dan penyerapan pikiran kita.

c. Pengetahuan Indrawi (perceptual)

Pengetahuan Indrawi adalah sesuatu yang dicapai dan diraih melalui indra-indra lahiriah. Sebagai contoh, kita menyaksikan satu pohon, batu, atau kursi, dan objek-objek ini yang masuk ke alam pikiran melalui indra penglihatan akan membentuk pengetahuan kita. Tanpa diragukan bahwa hubungan kita dengan alam eksternal melalui media indra-indra lahiriah ini, akan tetapi pikiran kita tidak seperti klise foto dimana gambar-gambar dari apa yang diketahui lewat indra-indra tersimpan didalamnya. Pada pengetahuan indrawi terdapat beberapa faktor yang berpengaruh, seperti adanya cahaya yang menerangi objek-objek eksternal, sehatnya anggotaangota indra badan (seperti mata, telinga, dan lain-lain), dan pikiran yang mengubah benda-benda partikular menjadi konsepsi universal, serta faktor-faktor sosial (seperti adat istiadat). Dengan faktor-faktor tersebut tidak bisa dikatakan bahwa pengetahuan indrawi hanya akan dihasilkan melalui indra-indra lahiriah.

d. Pengetahuan Konseptual (conceptual)
Pengetahuan konseptual juga tidak terpisah dari pengetahuan indrawi. Pikiran manusia secara langsung tidak dapat membentuk suatu konsepsi-konsepsi tentang objek-objek dan perkara-perkara eksternal tanpa berhubungan dengan alam eksternal. Alam luar dan konsepsi saling berpengaruh satu dengan lainnya dan pemisahan di antara keduanya merupakan aktivitas pikiran

e. Pengetahuan Partikular (particular)

Pengetahuan partikular berkaitan dengan satu individu, objek-objek tertentu, atau realitas-realitas khusus. Misalnya ketika kita membicarakan satu kitab atau individu tertentu, maka hal ini berhubungan dengan pengetahuan partikular itu sendiri.

f. Pengetahuan universal (universal)

Pengetahuan yang meliputi keseluruhan yang ada, seluruh hidup manusian misalnya; agama dan filsafat (Http://Referensiassyariabdullah.Blogsp ot.Com/2008/04/Definisi-Dan-Jenis-

Jenis-Pengetahuan.Html);

Adapun jenis-jenis pengetahuan ditinjau dari sudut bagaimana pengetahuan itu diperoleh, bukan pada bahasan nilai (value) dari pengetahuan tersebut antara lain:

a. Pengetahuan Biasa (common sense)

Pengetahuan biasa adalah pengetahuan yang digunakan terutama untuk kehidupan sehari-hari, tanpa mengetahui seluk beluk yang sedalam-dalamnya dan seluas-luasnya. Seorang yang dulunya belum tahu tentang 
cara belajar sesuatu hal dan setelah melalui suatu proses seseorang tahu tentang sesuatu hal tersebut, maka orang tersebut disebut memiliki pengetahuan biasa. Dalam bahasa lain disebut sebagai pengetahuan yang dimiliki dengan kadar sekedar tahu. Memenuhi faktor ketidaktahuannya.

b. Pengetahuan Ilmiah atau Ilmu Pengetahuan

Pengetahuan ilmiah atau Ilmu, pengetahuan yang diperoleh dengan cara khusus, bukan hanya untuk digunakan saja tetapi ingin mengetahui lebih dalam dan luas mengetahui kebenarannya, tetapi masih berkisar pada pengalaman. Pengetahuan Ilmiah atau Ilmu (Science) pada dasarnya merupakan usaha untuk mengorganisasikan dan mensistematisasikan common sense, suatu pengetahuan sehari-hari yang dilanjutkan dengan suatu pemikiran cermat dan seksama dengan menggunakan berbagai metode. Dari pengetahuan tentang misal hewan komodo yang sekedar tahu, kemudian menggunakan beberapa langkah dan metode yang jelas untuk mengetahui lebih dari sekedar tahu, dan dilakukan secara sistematis maka orang yang mengetahui dan memahami secara mendalam tentang hewan komodo tersebut dan disebut sebagai pengetahuan ilmiah tentang hewan komodo. Dalam batasan ini, seseorang yang memiliki pengetahuan ilmiah atau ilmu pengetahuan, maka semua proses yang dilewatinya jika dilakukan oleh orang lain akan memiliki pengetahuan yang sama dengan yang dimilikinya. Sebagian yang mendefinisikan pengetahuan sebagai sebuah ilmu. Ilmu merupakan suatu metode berfikir secara objektif yang bertujuan untuk menggambarkan dan memberi makna terhadap gejala dan fakta melalui observasi, eksperimen dan klasifikasi. Ilmu harus bersifat objektif, karena dimulai dari fakta, menyampingkan sifat kedirian, mengutamakan pemikiran logik dan netral.

c. Pengetahuan Filsafat

Pengetahuan filsafat, pengetahuan yang tidak mengenal batas, sehingga yang dicari adalah sebab-sebab yang paling dalam dan hakiki sampai diluar dan diatas pengalaman biasa. Pengetahuan Filsafat biasanya berkenaan dengan hakikat sesuatu (transenden) sehingga kadang perbincangannya seputar hal-hal yang abstrak terhadap banguan sebuah pengetahuan. Objek pembahasannya selalu mengedepanan aspek ontologi, epistimologi dan aksiologi. Pembahasan tentang Pengetahuan Filsafat akan di uraikan pada postingan tentang Hakikat Filsafat.

\section{i. Pengetahuan Agama}

Pengetahuan agama adalah pengetahuan yang hanya diperoleh dari Tuhan lewat para Nabi dan Rasul-Nya yang bersifat mutlak dan wajib diikuti para pemeluknya. Dengan menjadikan ajaran agama sebagai tolak ukur kebenaran, maka pengetahuan agama sangat 
sarat dengan nilai baik dan buruk, benar dan salah. Sepanjang pengetahuan itu tidak bertentangan dengan ajaran yang tertuang dalam kitab yang diperpegangi, maka pengetahuan itu dianggap benar (http://elearningpendidikan.com/ jenispengetahuan.html diakses 29 Oktober 2020);

\section{JENIS-JENIS ILMU PENGETAHUAN}

\section{Definisi Ilmu Pengetahuan}

Kata ilmu berasal dari bahasa Arab, yaitu 'alima-ya'lamu-'ilman yang artinya mengetahui, mengerti atau memahami (Kamus arab online: https://www.almaany.com diakses pada 3010-2020 pukul 7:53 WIB); Ilmu dalam bahasa Inggris disebut science, dan dalam bahasa Latin disebut scientia (pengetahuan)-scire (mengetahui). Sinonim yang paling dekat dengan bahasa Yunani adalah episteme (Jujun S. Suriasumantri, 2003: 104); Jadi ilmu, sains atau ilmu pengetahuan adalah usaha-usaha sadar untuk menyelidiki, menemukan dan meningkatkan pemahaman manusia dari berbagai segi kenyataan dalam alam manusia. Dari segi ini dibatasi agar menghasilkan rumusan-rumusan yang pasti. Karena ilmu memberikan kepastian dengan membatasi lingkup pandangannya, dan kepastian ilmu itu diperoleh dari keterbatasannya (Arief Sidharta, 2008: 7-11);

Ilmu bukan sekadar pengetahuan (knowledge), tetapi merangkum sekumpulan pengetahuan berdasarkan teori-teori yang disepakati dan dapat secara sistematik diuji dengan seperangkat metode yang diakui dalam bidang ilmu tertentu. Dipandang dari sudut filsafat, ilmu terbentuk karena manusia berusaha berpikir lebih jauh mengenai pengetahuan yang dimilikinya. Ilmu pengetahuan adalah produk dari epistemologi, dengan kata lain ilmu terbentuk dari 3 cabang filsafat yakni ontologi, epistemologi dan aksiologi, jika ketiga cabang itu terpenuhi berarti sah dan diakui sebagai sebuah ilmu (Arief Sidharta, 2008: 11);

Archie J. Bahm dalam tulisannya yang berjudul "Apa Itu Ilmu” (What is Science), mengatakan, ilmu pengetahuan terkait dengan masalah. Masalah adalah bagian dari ilmu pengetahuan. Jika tidak ada masalah, maka tidak akan muncul ilmu pengetahuan. Pengetahuan ilmiah adalah hasil dari pemecahan masalah ilmiah. Jika tidak ada masalah, maka tidak ada pemecahan masalah, dengan demikian tidak ada pengetahuan ilmiah. Untuk menjadi ilmiah, maka seseorang harus memiliki kemauan untuk mencoba memecahkan masalah (FX Joko Priyono, 2000: 1);

Menurut Bahm, ilmu pengetahuan setidaknya melibatkan enam komponen penting: 1) masalah (problems); 2) sikap (attitude); 3) metode (method); 4) aktivitas (activity); 5) kesimpulan (conclusion); 6) pengaruh (effects). 
1) Masalah (Problems) Masalah mana yang dianggap mengandung sifat ilmiah? Menurut Bahm, suatu masalah bisa dianggap ilmiah, sedikitnya memiliki tiga ciri: 1) terkait dengan komunikasi; 2) sikap ilmiah dan 3) metode ilmiah. Tidak ada masalah yang disebut ilmiah kecuali masalah tersebut bisa dikomunikasikan kepada orang lain. Jika belum atau tidak dapat dikomunikasikan kepada orang lain atau masyarakat maka belum dianggap ilmiah. Tidak ada masalah yang pantas disebut ilmiah kecuali masalah tersebut bisa dihadapkan pada sikap ilmiah. Demikian pula tidak ada masalah yang pantas disebut ilmiah kecuali harus terkait dengan metode ilmiah.

2) Sikap (attitude) Sikap ilmiah (scientific attitude) menurut Bahm setidaknya harus memiliki enam ciri pokok, yaitu: 1) keingintahuan (curiosity); Keingintahuan harus dimiliki oleh seorang ilmuwan, seperti keinginan untuk menyelidiki, investigasi, eksplorasi, dan eksperimentasi. 2) spekulasi (speculativeness); Hal ini penting dalam rangka menguji hipotesis. Spekulasi juga merupakan ciri penting dalam sikap ilmiah. 3) kemauan untuk berlaku objektif (willingness to be objective); Sikap ini penting, sebab objektivitas merupakan ciri ilmiah. Sikap demikian harus dimiliki oleh seorang ilmuwan. 4) terbuka (open-maindedness); artinya selalu bersedia menerima kritik dan saran ilmuwan lain secara lapang dada. 5) kemauan untuk menangguhkan penilaian (willingness to suspend judgment) artinya bersedia menangguhkan keputusan sampai semua bukti penting terkumpul. dan 6) bersifat sementara (tentativity) artinya harus menerima bahwa kesimpulan ilmiah bersifat sementara.

3) Metode (Method) Menurut Bahm, bahwa esensi dari sebuah pengetahuan adalah metode. Setiap pengetahuan memiliki metodenya sendiri sesuai dengan permasalahannya. Meski diantara para ilmuwan terjadi perbedaan tentang metode ilmiah, tetapi mereka sepakat bahwa masalah tanpa observasi tidak akan menjadi ilmiah, sebaliknya observasi tanpa masalah juga tidak akan menjadi ilmiah. Menurutnya, bahwa ilmu pengetahuan adalah aktivitas menyelesaikan masalah dan melihat metode ilmiah sebagai sesuatu yang memiliki karakteristik yang esensial bagi penyelesaian masalah. Ada lima langkah esensial dan ideal -menurut Bahmdalam menerapkan metode ilmiah yang harus dipahami oleh seorang peneliti (ilmuwan), yaitu 1) memahami masalah; 2) menguji masalah; 3) menyiapkan solusi; 4) menguji hipotesis dan 5) memecahkan masalah.

4) Aktivitas (Activity) Aktivitas dimaksud adalah penelitian ilmiah, yang memiliki 
dua aspek: individual dan sosial. Aktivitas penelitian ilmiah meliputi: 1) observasi; 2) membuat hipotesis, 3) menguji observasi dan hipotesis dengan cermat dan terkontrol.

5) Kesimpulan (Conclusion) Kesimpulan merupakan penilaian akhir dari suatu sikap, metode dan aktivitas. Kesimpulan ilmiah tidak pasti, tetapi bersifat sementara dan tidak dogmatis. Bahkan jika kesimpulan dianggap dogmatis, maka akan mengurangi sifat dasar dari ilmu pengetahuan tersebut. Pada dasarnya ilmu pengetahuan itu bersifat tidak stabil, setiap generasi berhak untuk menginterpretasikan kembali tradisi ilmu pengetahuan itu.

6) Pengaruh (Effects) Ilmu pengetahuan memiliki dua pengaruh, yaitu: 1) pengaruh terhadap teknologi dan industri; 2) pengaruh pada peradaban manusia. Industrialisasi yang berkembang dengan pesat merupakan produk dari ilmu pengetahuan yang mempunyai dampak besar terhadap perkembangan ilmu, sehingga nampak seperti yang terjadi dalam perubahan sifat ilmu itu sendiri. Proses industrialisasi tidak akan dapat diputarulang yang akhirnya ilmu pengetahuan itu sendiri mengalami proses terindustrialisasi. Ilmu pengetahuan yang terindustrialisasi ini menjadi bagian utama dari penggerak ilmu pengetahuan dan menjadi sebuah sumber bidang penelitian yang memiliki prestise tinggi (FX Joko Priyono, 2000: 1);

Dari sini dapat dipahami bahwa ilmu sangat erat kaitannya dengan masalah, dan masalah tersebut itulah yang nantinya akan menjadi pengetahuan dan bisa dinyatakan pengetahuan ilmiah jika melibatkan komponen-komponen ilmu pengetahuan ilmiah.

\section{Ciri-ciri Ilmu Pengetahuan}

Ilmu pengetahuan dibangun dengan metode untuk mendapatkan hasil yang dapat diakui keabsahannya, maka untuk itu terdapat ciri-ciri ilmu pengetahuan sebagai berikut:

a) Sistematis.

Ilmu pegetahuan bersifat sistematis, artinya ilmu pengetahuan ilmiah dalam upaya menjelaskan sesuatu teori, dengan kata lain teori dipergunakan sebagai alat utuk menjelasakan gejala dari kehidupan sehari-hari, ciri sistematis ilmu pengetahuan dapat digambarkan sebagai berikut:

5. Persepsi sehari-hari

Berdasarkan perespsi sehari-hari terhadap fenomena yang disampaikan dalam bahasa sehari-hari, kemudian diobservasi agar menghasilkan makna.

6. Observasi

Untuk menyusun konsep ilmiah maka dibutuhkan definisi. Dimana definisi ini akan mempertegas objek yang yang akan diteliti. 


\section{Hipotesis}

Berawal dari konseo ilmiah yang merupakan pernyataan-pernyataan yang mengandung informasi dan kedua penrnytaan tersebut digabung menjadi preposisi dan preposisi tersebut diuji kebenarannya.

8. Hukum

Adalah hipotesis yang sudah diuji kebenarannya disebut dalil hukum.

\section{Teori}

Keseluruhn dalil atau hukum yang tidak bertentangan satusama lain dan dapat menjelskan fenomena tersebut (Imam Gunawan, 2016: 7-8);

Tahapan tersebut merupakan gambaran bahwa untuk menyusun persepsi sampai kepada teori yang pada muaranya jika dikelompokan menjadi cabang ilmu, maka penyusun memaknai bahwa sistematika dalam penyusunan untuk menjadi ilmu adalah hal yang sangat penting, sehinga ilmu dapat dijelaskan karena memiliki metode tertentu dan jelas tahapan penyusunannya.

b) Bisa Dipertanggungjawabkan

Ilmu pengetahuan ilmiah dapat dipertanggung jawabkan memlalui tiga macam sistem sebagai berikut:

1. Sistem Aksiomatis

Sistem ini berupaya untuk membuktikan kebenaran suatu fenomena atau gejala sehari-hari mulai dari kaidah umum atau rumus umum menuju rumus konkret.

\section{Sistem Empirik}

Sistem ini berusaha membuktikan kebenaran suatu gejala khusus menuju ke umum.

\section{Sistem Semantik/Linguistik}

Sistem ini kebenarannya didapatkan dengan menyusun preposisi-preposisi secara ketat, umumnya menggunakan metode ini adalah ilmu bahasa (Imam Gunawan, 2016: 9);

Penulis menyimpulkan bahwa sifat dapat dipertangung jawabkan menjadi sifat wajib ilmu, sebab setiap tahapannya tersusun secara jelas dengan objek yang jelas. Hal ini pada hakikatnya jelas dapat dilakukan sebagaiman telah dijelaskan, ditambah dengan tolak ukur ilmu pengetahuan telah disusun sesuai denga jenis dan bidangnya maka hal ini membuat ilmu harus dapat dipertanggung jawabkan.

c) Objektif atau Intersubjektif

Ilmu pengetahuan bersifat mandiri atau milik orang banyak. Ilmu pengetahuan bersifat otonom dan mandiri, bukan milik perorangan (subjektif) tetapi antar subjek kegiatan ilmiah. Dengan kata lain ilmu pengetahuan harus ditopang oleh komunitas ilmiah (Imam Gunawan, 2016: 10);

Jujun S. Suriasumantri juga menjeaskan secara spesifik bahwa ilmu adalah suatu pengetahuan yang mencoba menjelaskan 
10) Rasional;

unsur-unsurnya

rahasia alam agar gejala alamiah tersebut tidak lagi merupakan misteri. Untuk itu ilmu membatasi ruang jelajah kegiatannya pada daerah pengalaman manusia. Artinya, obyek penelaahan keilmuan meliputi segenap gejala yang dapat ditangkap oleh pengalaman manusia melalui panca indranya (Jujun S. Sumantri, 2001: 65-68);

Adapun ciri-ciri ilmu yaitu:

1) Komprehensif; ruang lingkupnya luas dan lengkap.

2) Sinoptik; unsur-unsurnya memiliki kebersamaan yang integral.

3) Sistematik; teratur menurut sistem, ada korelasi.

4) Memiliki obyek kajian yang jelas.

5) Relatif; bersifat sementara dan terbuka terhadap penemuan baru, kreatif dan pragmatis.

6) Kebenaran ilmiah tidaklah bersifat difinitif, suatu teori keilmuan yang dipandang benar pada kurun waktu tertentu, mungkin saja salah dalam kurun waktu yang lain.

7) Koheren; runtut, unsur-unsurnya tidak boleh mengandung uraian-uraian yang bertentangan satu sama lain.

8) Sistematis; masing-masing unsur saling berkaitan satu sama lain, ada sistem dalam susunan pengetahuan dan dalam cara memperolehnya.

berhubungan secara logis.

11) Intersubjektif, kepastian pengetahuan ilmiah tidaklah didasarkan atas intuisiintuisi serta pemahaman-pemahaman secara subjektif, melainkan dijamin oleh sistemnya itu sendiri.

12) Bersifat empiris, berdasarkan pengalaman, penemuan, pengamatan, percobaan yang telah dilakukan.

13) Kognitif; pernyataan yang terkait dengan keilmuan itu memang bersifat mengandung hakikat kebenaran itu sendiri.

14) Mempunyai dasar pembenaran/ postulat; cara kerja ilmiah diarahkan untuk smemperoleh derajat kepastian yang sebesar mungkin.

15) Otonom; mempunyai kedudukan mandiri. Maksudnya, meskipun faktorfaktor di luar ilmu juga ikut berpengaruh, tetapi harus diupayakan agar tidak menghentikan pengembangan ilmu secara mandiri.

16) Memiliki hubungan fungsional dan hubungan kausal. Ilmu harus dapat digunakan sebagai perwujudan kebertautan antara teori dan praktis.

17) Ilmu harus bersifat tampa pamrih, karena hal itu erat kaitannya dengan tanggung jawab ilmuan)

9) Konsepsional; jelas prosesnya. 
18) Objektif; setiap ilmu terpimpin oleh obyek dan tidak didistorsi oleh prasangka-prasangka subjektif.

19) Progresif; suatu jawaban ilmiah baru bersifat ilmiah sungguh-sungguh bila mengandung pertanyaan-pertanyaan baru dan menimbulkan problemproblem baru lagi.

20) Universal; berlaku umum (untuk semua orang atau untuk seluruh dunia). Jawaban atas pertanyaan apakah sesutu hal itu layak atau tidak layak tergantung pada faktor-faktor subjektif (Jujun S. Sumantri, 2001: 65-68);

Ciri-ciri ilmu sebagaimana yang dijabarkan oleh Jujun S. Sumantri di atas, menunjukkan bahwa kaidah keilmuaan sangat syarat dengan metode ilmiah yang digunakan. Dimana metode ilmiah inilah yang menjadi kata kunci dalam ilmu. Metode yang ilmiah akan menghasilkan pengetahuan yang bersifat ilmiah yang kita pahami sebagai ilmu.

Adapun menurut The Liang Gie dalam Surajiyo, ilmu pengetahuan atau pengetahuan ilmiah mempunyai lima ciri pokok, yaitu:

1. Empiris; pengetahuan itu diperoleh berdasarkan pengamatan dan percobaan.

2. Sistematis; berbagai keterangan dan data yang tersusun sebagai kumpulan pengetahuan itu mempunyai hubungan ketergantungan dan teratur.
3. Objektif; ilmu berarti pengetahuan itu bebas dari prasangka perseorangan dan kesukaan pribadi.

4. Analitis; pengetahuan ilmiah berusaha membeda-bedakan pokok soalnya ke dalam bagian yang terperinci untuk memahami berbagai sifat, hubungan, dan peranan dari bagian-bagian itu.

5. Verifikatif; dapat diperiksa kebenarannya oleh siapa pun juga (Surajiyo, 2008: 6164);

\section{Jenis-jenis Ilmu Pengetahuan}

Terkait penggolongan jenis-jenis ilmu para ahli kebanyakan tidak merincikan berbagai cabang ilmu, hanya biasanya diberikan contoh ilmu apa yang termasuk dalam masing-masing kelompok. Penggolongan ilmu pengetahuan sebagaimana dikutip dari Surajiyo ${ }^{21}$ adalah sebagai berikut:

a. Ilmu Formal dan Ilmu Nonformal

Suatu ilmu disebut Ilmu Formal karena ilmu ini dalam seluruh kegiatannya tidak bermaksud menyelidiki data-data indrawi yang konkret. Misalnya matematika dan filsafat. Suatu ilmu disebut Ilmu Nonformal karena di dalam ilmu ini pengalaman inderawi memainkan peranan sentral/utama. Ilmu ini dalam seluruh kegiatannya berusaha menyelidiki secara sistematis data-data inderawi yang konkret. Misalnya ilmu hayat, ilmu alam, dan ilmu manusia.

b. Ilmu Murni dan Ilmu Terapan 
Ilmu Murni adalah ilmu yang bertujuan meraih kebenaran demi kebenaran (teoretis). Misalnya matematika dan metafisika. Ilmu Terapan adalah ilmu yang bertujuan untuk diaplikasikan atau diambil manfaatnya (praktis). Misalnya ilmu kedokteran, teknik, hukum, ekonomi, psikologi, sosiologi, administrasi, dan ekologi.

c. Ilmu Nomotetis dan Ilmu Idiografis

Ilmu Nomotetis adalah ilmu yang objek pembahasannya merupakan gejala pengalaman yang dapat diulangi terusmenerus dan hanya merupakan kasus-kasus yang mempunyai hubungan dengan suatu hukum alam. Termasuk dalam ilmu ini adalah ilmuilmu alam, yang objek pembahasannya adalah benda alam atau gejala alam, yang didekati dengan cara menerangkan.

Ilmu Idiografis adalah ilmu yang objek pembahasannya merupakan objek yang bersifat individual, unik, yang hanya terjadi satu kali dan mencoba mengerti atau memahami objeknya menurut keunikannya itu. Termasuk dalam ilmu ini adalah ilmuilmu budaya, yang objek pembahasannya adalah produk manusiawi, yang didekati dengan cara mengerti atau memahami.

\section{d. Ilmu Deduktif dan Ilmu Induktif}

Suatu ilmu disebut Ilmu Deduktif karena semua pemecahan yang dihadapi dalam ilmu ini tidak didasarkan atas pengalaman inderawi (empiris), melainkan atas dasar deduksi atau penjabaran. Deduksi ialah proses pemikiran yang melibatkan akal budi manusia dari pengetahuan tentang halhal yang umum dan abstrak, menyimpulkan tentang hal-hal yang bersifat khusus dan individual. Misalnya matematika.

Suatu ilmu disebut Ilmu Induktif apabila penyelesaian masalah-masalah dalam ilmu yang bersangkutan didasarkan atas pengalaman inderawi (empiris). Ilmu Induktif bekerja selalu atas dasar induksi, yaitu proses pemikiran yang melibatkan akal budi manusia dari pengetahuan tentang hal-hal yang bersifat khusus dan individual, menarik kesimpulan tentang hal-hal yang bersifat umum dan abstrak. Misalnya ilmu alam.

Van Melsen membedakan llmu pengetahuan menjadi ilmu-ilmu empiris (ilmu alam, ilmu sejarah, ilmu-ilmu manusia) dan ilmu-ilmu nonempiris (matematika dan filsafat) (Van Melsen, 1992: 25-47);

1. Ilmu alam

Ilmu alam ini melukiskan kenyataan menurut aspek-aspek yang dapat diinderawi secara langsung. Data inderawi ini harus dimengerti sebagaimana tampaknya. Hal ini dapat dilakukan melalui observasi ilmiah yang memiliki objektivitas pada objek. Ilmu alam menyelidiki kenyataan konkret menurut aspek-aspeknya yang dapat diulangi.

2. Ilmu sejarah

Ilmu sejarah yang dimaksud adalah ilmu yang menyangkut sejarah manusia. Ilmu sejarah ini menyelidiki segala sesuatu yang 
berhubungan dengan tindakan manusiawi, yang dapat juga diungkapkan melalui peninggalan-peninggalan fisis. Karena sejarah meliputi semua kejadian yang pernah berlangsung, akibatnya ilmu sejarah ini tidak bias mengadakan eksperimen.

\section{Ilmu-ilmu manusia}

Ilmu ini juga disebut ilmu-ilmu tingkah laku (behavioral science) atau ilmu-ilmu sosial. Ilmu-ilmu manusia ini diberi tempat tersendiri di samping ilmu sejarah dan ilmu alam, karena ilmu sejarah maupun ilmu manusia menyangkut perbuatan serta tingkah laku manusia. Di samping itu, ilmu manusia juga mempunyai persamaan dengan ilmu alam, dengan usahanya untuk menemukan secara khusus aspekaspek yang dapat diulangi.

\section{Matematika}

Matematika merupakan ilmu nonempiris dan dalam bentuk abstrak yang juga mempunyai peranan penting dan dapat diterapkan bagi ilmu-ilmu empiris. Karena keabstrakan matematika ini, ia menyediakan berbagai struktur formal bagi ilmu-ilmu lain.

\section{Filsafat}

Filsafat juga merupakan ilmu nonempiris, yang berfungsi sebagai kerangka sistematis yang umum, mengingat adanya pandangan bahwa filsafat sebagai induk semua ilmu lain. Dalam keanekaragaman ilmu ini perlu diteruskan pencarian jawaban atas pertanyaan yang pada awal mulanya dikemukakan oleh filsafat.

\section{PERSAMAAN DAN PERBEDAAN} ANTARA PENGETAHUAN DAN ILMU PENGETAHUAN

Sebagaimana penulis telah uraikan di atas terkait definisi pengetahuan dan ilmu pengetahuan, maka dalam hal ini penulis menegaskan kembali tentang persamaan dan perbedaan antara pengetahuan dan ilmu pengetahuan itu sebagai berikut:

1. Persamaan:

- Pengetahuan dan ilmu pengetahuan pada dasarnya memiliki arti yang sama, yaitu analisa terhadap suatu hal berdasarkan metode ilmiah hanya saja penggunaannya tergantung dari sifat dan tujuan yang hendak dicapai dalam kegiatan keilmuan tersebut.

- Keduanya sangat sulit untuk dipisahkan karena merupakan pengetahuan tentang sesuatu hal atau fenomena, baik yang menyangkut alam atau sosial (kehidupan masyarakat), yang diperoleh manusia melalui proses berfikir. Itu artinya bahwa setiap ilmu merupakan pengetahuan tentang sesuatu yang menjadi objek kajian dari ilmu terkait (Casimiro Da Assuncao Pires, 2018: 4-5);

2. Perbedaan:

- Pengetahuan adalah hasil pengamatan yang bersifat tetap, karena tidak 
memberikan tempat bagi pengkajian dan pengujian secara kritis oleh orang lain, dengan demikian tidak bersifat sistematik dan tidak objektif serta tidak universal. Sedangkan ilmu pengetahuan adalah kerangka konseptual atau teori yang saling berkaitan yang memberi tempat pengkajian dan pengujian secara kritis dengan metode ilmiah oleh ahli-ahli lain dalam bidang yang sama, dengan demikian bersifat sistematik, objektif, dan universal.

- Ilmu adalah sesuatu yang dapat kita peroleh melalui proses yang disebut pembelajaran atau metode ilmiah dengan kata lain hasil dari pembelajaran, berbeda dengan Pengetahuan yang dapat diperoleh tanpa melalui proses pembelajaran (Lia Aulia fachrial, tanpa tahun: 8);

- Ilmu adalah kumpulan pengetahuan. Namun bukan sebaliknya kumpulan ilmu adalah pengetahuan. Kumpulan pengetahuan agar dapat dikatakan ilmu harus memenuhi syarat-syarat tertentu. Syarat-syarat yang dimaksudkan adalah objek material dan objek formal. Objek material adalah sesuatu hal yang dijadikan sasaran pemikiran, sesuatu hal yang diselidiki atau sesuatu hal yang dipelajari. Objek material mencakup hal konkrit misalnya manusia, tumbuhan, batu ataupun hal-hal yang abstrak seperti ide-ide, nilai-nilai, dan kerohanian. Sedangkan objek formal adalah cara memandang, cara meninjau yang dilakukan oleh peneliti terhadap objek materialnya serta prinsip-prinsip yang digunakannya. Objek formal dari suatu ilmu tidak hanya memberi keutuhan suatu ilmu, tetapi pada saat yang sama membedakannya dari bidang-bidang yang lain. Satu objek material dapat ditinjau dari berbagai sudut pandangan sehingga menimbulkan ilmu yang berbeda-beda (A. Mudhofir, 2005: 27); Setiap bidang ilmu baik itu ilmu khusus maupun ilmu filsafat harus memenuhi ke dua objek tersebut.

\section{CABANG - CABANG ILMU PENGETAHUAN}

Dalam kaitannya dengan cabang-cabang ilmu pengetahuan penulis mengutip pendapat Ahmad Tafsir dalam bukunya "Filsafat Umum" (Ahmad Tafsir, 2007: 25-27), yaitu sebagai berikut:

1. Sain Kealaman

2. Astronomi

3. Fisika (Mekanika, Optik, Fisika Nuklir)

4. Kimia (Organik, Teknik)

5. Ilmu Bumi (Paleontologi, Ekologi, Geofisika, Geografi, Mineralogi)

6. Ilmu Hayat (Biofisika, Botani, Zoologi)

7. Sain Sosial

8. Sosiologi (Komunikasi, Politik, Sosiologi Pendidikan) 
9. Antropologi (Budaya, Antropologi Ekonomi, Antropologi Politik)

10. Psikologi (Psikologi Pendidikan, Psikologi Anak, Psikologi Abnormal)

11. Ekonomi (Ekonomi Makro, Ekonomi Lingkungan, Ekonomi Pedesaan)

12. Politik (Politik Dalam Negeri, Politik Hukum, Politik Inter nasional)

13. Humaniora

14. Seni (Abstrak, Grafika, Pahat, Tari, Seni Rupa)

15. Hukum (Pidana, Tata Usaha Negara, Adat)

16. Filsafat (Logika, Ethika, Estetika)

17. Bahasa (Sastra)

18. Agama

\section{SIMPULAN}

Dari uraian di atas penulis menarik kesimpulan sebagai berikut:

1. Ilmu pengetahuan dapat disebut sebagai suatu metode berfikir secara objektif dalam menggambarkan dan memberi makna terhadap dunia faktual dan berprinsip untuk mengorganisasikan dan mensistematisasikan common sense (akal sehat). Sedangkan Pengetahuan merupakan hasil dari proses usaha manusia untuk menjadi tahu, sehingga ilmu pengetahuan merupakan kumpulan pengetahuan yang benar-benar disusun dengan sistematis dan metodologis untuk mencapai tujuan yang berlaku universal dan dapat diuji atau diverifikasi kebenarannya.

2. Ilmu pengetahuan adalah kumpulan pengetahuan. Namun bukan sebaliknya kumpulan ilmu pengetahuan adalah pengetahuan. Kumpulan pengetahuan agar dapat dikatakan ilmu pengetahuan harus memenuhi syarat-syarat tertentu. Syaratsyarat yang dimaksudkan adalah objek material dan objek formal.

3. Pengetahuan ilmiah adalah segenap hasil pemahaman manusia yang diperoleh dengan menggunakan metode ilmiah. Pengetahuan ilmiah adalah pengetahuan yang sudah lebih sempurna karena telah mempunyai dan memenuhi syarat-syarat tertentu dengan cara berpikir yang khas, yaitu metodologi ilmiah.

4. Pengetahuan Ilmiah berhubungan dengan ilmu pengetahuan. Setiap pengetahuan ilmiah merupakan ilmu pengetahuan, namun tidak semua ilmu pengetahuan adalah pengetahuan ilmiah. Hal ini disebabkan karena adanya pengetahuanpengetahuan yang tidak ilmiah, misalnya mitos. 


\section{DAFTAR PUSTAKA}

Abdulah, Assyari, Definisi Dan Jenis Jenis Pengetahuan: Http://Referensiassyariabdullah.Blogspot.Com/2008/04/Definisi-Dan-Jenis-JenisPengetahuan.Html

Al-Ghazali, Imam, , tanpa tahun, al-Risalah al-Laduniyah dalam Majmu'atu Rasail, Kairo: Maktabah Taufiqiyah.

Fachrial, Aulia, Lia, M.Si, tanpa tahun, Pengetahuan dan Ilmu pengetahuan, makalah PPT.

Mudhofir, A., 2005, Pengenalan Filsafat-Filsafat Ilmu, Cet. ketiga, Yogyakarta: Penerbit Liberty.

Gunawan, Imam, 2016, Metode Penelitian Kualitatif Teori dan Praktik, Cet. IV, Jakarta: PT Bumi Aksara.

Https://Kbbi.Kemdikbud.Go.Id

Irawan, Bambang, Intuisi Sebagai Sumber Pengetahuan: Tinjauan Terhadap Pandangan Filosof Islam, Institut Agama Islam Negeri (IAIN) Sumatera Utara, TEOLOGIA, VOL. 25, NO. 1, Jan-Jun 2014.

Isyraq, Substansi Dan Definisi Pengetahuan:

Http://Isyraq.Wordpress.Com/2007/11/26/Substansi-Dan-Definisi-Pengetahuan/

Lestari, Suci, Indah, Sumber-Sumber Pengetahuan dan Macam-Macam Dimensi Filsafat Ilmu, https://www.kompasiana.com/indah98930/5da890d40d82303b934f4032/sumbersumber-pengetahuan-dan-macam-macam-dimensi-filsafat-ilmu?page $=2$

Makbul, M., tanpa tahun, Filsafat Ilmu: (Filsafat Ilmu, Kasifikasi Ilmu, Ciri-ciri Ilmu, dan Sistem Kerja Keilmuan), Makalah Seminar, UIN Alauddin Makassar.

Melsen, Van, 1992, Ilmu Pengetahuan dan Tanggung Jawab Kita (terj. K. Bertens), Jakarta: Gramedia.

Oktaviandry, Navel, Pengetahuan Ilmiah, Penelitian Ilmiah, Dan Jenis Pengetahuan: Http://Navelmangelep.Wordpress.Com/ 2012/ 02/ 21/ Pengetahuan PengetahuanIlmiah-Penelitian-Ilmiah-Dan-Jenis-Penelitian/

Sholikhati, Anisa, dkk., 2012, Jenis-Jenis Pengetahuan, Semarang: Makalah Program Magister Teknik Kimia Program Pasca Sarjana Universitas Diponegoro.

Djailani, Ririn M., Filsafat Ilmu, https://sites.google.com/site/auroranight0912/filsafatilmu/sumber pengetahuan

Waksena, Jenis Pengetahuan: http://elearningpendidikan.com/ jenis-pengetahuan.html

Kamus arab online: https://www.almaany.com

Pires, Da Assuncao, Casimiro, 2018, Perbedaan Ilmu Dengan Pengetahuan, Makalah, Universitas Airlangga, Surabaya, Indonesia. 
https://www.researchgate.net/publication/327418530_Perbedaan_Ilmu_dengan_Pengetahuan Priyono SH.,M.Hum., FX Joko, Resensi buku Archie J. Bahm "Apa Itu Ilmu” (What is Science), Semarang: Universitas Dipoengoro, 12-September 2000. Lihat juga di: eprints.undip.ac.id/20634/1/2471-ki-fh-02.pdf

Sugiyono, 2008, Metode Penelitin Kuantitatif dan R\&D, Bandung: Alfabeta, cet IV.

Surajiyo, 2008, Filsafat Ilmu dan Perkembangannya di Indonesia, Jakarta: Bumi Aksara.

Suriasumantri, Jujun S., 2003, Filsafat Ilmu Sebuah Pengantar Populer, Jakarta: Pustaka Sinar Harapan. , 2001, Ilmu dalam Perspektif, Cet. XV, Jakarta: Yayasan Obor Indonesia.

Sidharta, Arief, 2008, Apakah Filsafat dan Filsafat Ilmu Itu?, Bandung: Pustaka Sutra.

Tafsir, Ahmad, 2007, Filsafat Umum, Bandung: PT. Remaja Rosdakarya.

Winartha, I Made, 2006, Metodologi Penelitian Sosial Ekonomi, Yogyakarta: C.V. Andi Offset. 